Bulletin UASVM Food Science and Technology 70(1)/2013, 70-71

ISSN-L 2344-2344; Print ISSN 2344-2344; Electronic ISSN 2344-5300

\title{
Polarimetric Determination of Starch in Raw Materials and Discharged Waste from Beer Production
}

\section{Anca FĂRCAŞ, Maria TOFANĂ, Sonia SOCACI, Stăncuţa SCROB, Liana SALANŢĂ, Doiniţa BORŞ}

Faculty of Food Science and Technology, University of Agricultural Sciences and Veterinary Medicine, 35 Mănăştur Street, 400372, Cluj-Napoca, Romania; anca.farcas@usamvcluj.ro

\begin{abstract}
Brewer's spent grain (BGS) is a by-product of the brewing process, consisting of the solid fraction of barley malt remaining after separation of worth. In this research, raw materials and discharged waste from beer production were evaluated on the basis of starch content, using Ewers polarimetric method.
\end{abstract}

Keywords: starch, polarimeter, optical rotation, malt, brewers' spent grain, black beer.

Introduction. In preparation for brewing, barley is malted in a controlled germination process, which serves to increase the enzymatic content of the grain. During malting, enzymes break down the cell structure of the endosperm, releasing nutrients necessary for yeast growth and making the starch available for enzyme degradation during mashing. Starch, accounting for about 60 to $65 \%$ of the malt's weight, is composed of amylose, which is reduced to maltose and maltotriose and amylopectins that decompose into glucose (Bamforth, 2003).

Brewer's spent grain (BGS) is a by-product of the brewing process, consisting of the solid residue remaining after mashing and lautering; it consists primarily of grain husks and other residual compounds not converted to fermentable sugars by the mashing process (Xiros and Christakopoulos, 2009). BSG is produced in the largest quantity, corresponding to around $85 \%$ of the total generated and it is estimated that about $200 \mathrm{t}$ of wet spent grain with 70 to $80 \%$ water content are produced per $10.000 \mathrm{hl}$ of produced beer (Kunze, 1996).

Aims and objectives. Raw materials and discharged waste from beer production were evaluated on the basis of starch content, using Ewers polarimetric method. This method was used because it provides accurate results even in samples which contain proteins, sugars and hemicellulose in high quantities.

Materials and methods. All the materials (malt, brewers' spent grain) were supplied by the microbrewery of the Faculty of Food Science and Technology. The BSG used in this work was obtained from a process employing $100 \%$ malt, without addition of other cereal adjuncts. Caramelized and black malt are added in smaller quantities (5-10\%) to obtain darker colors and to enhance flavor characteristics. The polarimetric determination of starch content is based on the optically activity of starch. Due to the fact, that starch cannot be dissolved in water, hydrochloric acid is used. After dissolution, the sample needs to be clarified, filtrated and measured in a polarimeter. The optical rotation of all samples was measured at $20^{\circ} \mathrm{C}$ by using a sample cell of $200 \mathrm{~mm}$ optical path length. Results are presented as the mean of two replications with standard deviation. Moisture was determined by weight difference before and after heating at $130{ }^{\circ} \mathrm{C}$ for $1.5 \mathrm{~h}$. 
Results and Discussion. Chemically, BSG is rich in polysaccharides, protein and lignin. Robertson et al., 2010 stated that residual starch can contribute up to $13 \%$ of the dry weight and the spent grain from lager malts has higher protein content than that from ale. The starch level present in brewers spent grain was negligible, $5.09 \pm 0.08 \%$ due to extensive amylolysis during mashing, compared with the level found in malt $(57.78 \pm 0.34 \%, w / w)$. A similar value was also reported in studies of Makowska et al., 2013, which identified the grains starch content of $4.56 \pm 0.42 \%$; similar values were also reported, both for malts and brewers spent grain by Waters et al., 2012.

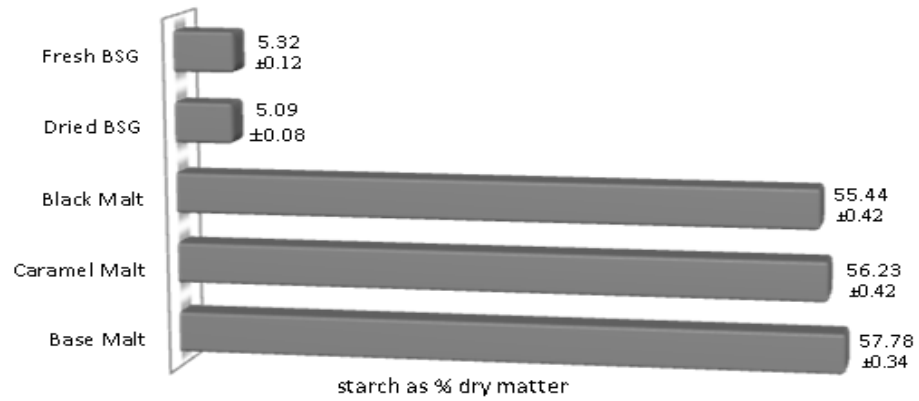

Fig. 1. Starch content in malt and brewers' spent grain samples ( $\%$ of dry matter)

Dry matter content of the test sample

\begin{tabular}{|l|c|c|c|c|c|}
\hline Type & Base Malt & Caramel Malt & Black Malt & Fresh BSG & Dried BSG \\
\hline Dry matter \% & 91.89 & 93.92 & 95.24 & 24.11 & 94.76 \\
\hline
\end{tabular}

Tab. 1

Conclusion. Chemical composition of BSG varies according to barley variety, harvest time, malting and mashing condition, type and quality of secondary raw materials and the brewing process. Methods used to determine the starch provides accurate results which are in accordance with values reported in the literature.

\section{REFERENCES}

1. Bamforth C. W. ( 2003). Barley and Malt Starch Review. MBAA TQ. vol. 40, no. 2, 89:97.

2. Kunze, W. (1996). Technology Brewing and Malting. VLB Berlin.

3. Makowska, Agnieszka; Mildner-Szkudlarz, Sylwia; Obuchowski, W. (2013). Effect of Brewer's Spent Grain Addition on Properties of Corn Extrudates with an Increased Dietary Fibre Content. Polish Journal of Food Nutrition Sciences. Vol. 63, No. 1

4. Native starch - Determination of starch content - Ewers polarimetric method, International Standard, ISO 10520:1997(E).

5. Robertson, J.A.; I'Anson, Kerry; Treimo, Janneke; Faulds,C.B.; Brocklehurst T.; Eijsink, V.; Waldron, K. (2010). Profiling brewers' spent grain for composition and microbial ecology at the site of production. LWT - Food Science and Technology. 43, 890:896.

6. Xiros, C.; Christakopoulos, P. (2009). Enhanced ethanol production from brewer's spent grain by a Fusarium oxysporum consolidated system. Biotechnology for Biofuels. 2:4.

7. Waters, Deborah M.; Jacob, F.; Titze, J.; Arendt, K.E.; Zannini, E. (2012). Fibre, protein and mineral fortification of wheat bread through milled and fermented brewer's spent grain enrichment. Eur Food Res Technol 235:767-778. 